\title{
Protein quality and digestibility of different parts (spathe and spadix) of Colocasia esculenta var. antiquorum flower
}

\author{
Esther Etengeneng AGBOR ${ }^{1 *}$, Lucie Carolle KENMOGNE ${ }^{2}$, \\ Joseph TCHOUMBOUE ${ }^{1}$ and I. B. UMOH ${ }^{3}$ \\ ${ }^{1}$ University of Dschang, Cameroon \\ ${ }^{2}$ University of Buea, Cameroon \\ ${ }^{3}$ University of Calabar, Nigeria \\ *Corresponding author, E-mail: agboresther@yahoo.co.uk; Phone: +237 77714871
}

\begin{abstract}
A rat growth and balance study was conducted to determine the protein quality and digestibility of the cooked spathe and spadix. Twenty-four (24) weanling male wistar rats were distributed in four groups of six elements. Test groups received respectively spathe- based, spadix-based and spadix + spathe-based diets. Each protein product was fed as the sole source of $10 \%$ dietary protein. The evaluated biological parameters were protein efficiency ratio (PER), net protein ratio (NPR) and true protein digestibility (TPD). The cooked spadix contained higher values of crude lipid $(10.8 \% \mathrm{DM})$, crude protein $(18.73 \% \mathrm{DM})$, and crude fibre $(34.47 \% \mathrm{DM})$ while spathe had higher values of crude ash $(9.26 \% \mathrm{DM})$, cellulose $(8.20 \% \mathrm{DM})$, phytate $(0.06 \mathrm{mg} / 100 \mathrm{~g} \mathrm{DM})$, cyanide $(0.25 \mathrm{mg} / 100 \mathrm{~g} \mathrm{DM})$ and total oxalate $(880.0 \mathrm{mg} / 100 \mathrm{~g} \mathrm{DM})$. Spathe showed significantly $(\mathrm{p}<0.05)$ a lower PER (1.00), NPR (1.42) and TPD (53.00\%) compared to spadix. Spadix+ spathe mixture showed the highest values of PER (1.76), NPR (2.11) and TPD (60.72\%) compared to spathe and spadix separately, though there was no significant difference $(p>0.05)$ between the TPD of spadix and spadix + spathe mixture. The presence of higher levels of cellulose, phytate and hydrocyanide in spathe could have been responsible for the lower protein digestibility and quality observed.

(C) 2009 International Formulae Group. All rights reserved.
\end{abstract}

Keywords: Colocosia esculenta, cocoyam, cooked spadix, cooked spathe, PER, NPR, TPD.

\section{INTRODUCTION}

Colocasia esculenta var. antiquorum (or eddoe type or Japanese type) is a varietal type of Colocasia esculenta which produces a small to medium-sized corm and numerous cormels (Agbor-Egbe, 1991). It consists of a central corm from which cormels, roots and shoot arise (Onwueme, 1999). The shoot consists of a large leaf lamina, an erect petiole and flower (though flowering is occasional). The flower consist of a spathe $(20-40 \mathrm{~cm}$ long) enclosing a spadix (6-14 cm long) which contains unisexual seeds (Wilfred, 1999).

In Cameroon, rural dwellers use the flower of Colocasia esculenta var. antiquorum as a thickener in soups and as vegetables. Leaf vegetables are known to be rich in mineral elements, vitamins and proteins (Aletor and Adeogun, 1995).The protein quality of leaf vegetables is constrained by amino acid composition and intrinsically present anti-nutritional factors (Frake and Sharma, 1986; Aletor and Fetuga, 1988; Aletor, 1993; Aletor and fasuyi, 1997; Oguntona, 1998; Kannan et al., 2001; Sarwar et al., 2005). The flower of Colocasia esculenta var. antiquorum contained significant amounts of nutrients (Ejoh et al., 1996; Agbor et al., 2005). Agbor et al. (2005) discovered that spadix of flower contained more crude lipid, crude protein and crude fiber than the spathe. However, different parts 
of a plant can have different nutrient contents and nutrient bioavailability (Hume and Purser, 1975; Ru and Fortune, 2000; Sundriyal and Sundriyal, 2004; Ebianadon et al., 2009).

Ignorantly, some consumers of this flower consume the spathe and throw away the spadix. Also, there is paucity of information on the protein quality of spathe and spadix of this flower. The purpose of this study, therefore, was to evaluate the protein quality and digestibility of different parts of Colocasia esculenta var. antiquorum flower.

\section{MATERIALS AND METHODS \\ Preparation of cooked samples}

Fresh samples of flower (spathe and spadix) were brought from farmers in Dschang municipality, Cameroon. The spathe and spadix were separately washed with clean water and sliced using a stainless knife. The spliced samples were separately cooked $(2 \mathrm{~kg}$ of samples with one liter of clean water) to dryness for one hour in stainless pots using a kitchen gas cooker (Arkays Double Burner Gas Stove, Model N ${ }^{\circ}$ JNY-TH2). The cooked samples were separately cooled for 30 minutes and dehydrated in a moisture extraction oven at an average temperature of $60 \pm 2{ }^{\circ} \mathrm{C}$ for 12 hours. The cooked and dehydrated samples were separately ground using an electric blender (Moulinex Blender, Ref 0817896) to obtain meals which were stored in identified tightly corked stainless containers awaiting chemical analysis and formulation of test diets.

\section{Chemical analyses}

The cooked, dehydrated and ground samples of spathe and spadix were separately analyzed for proximate composition, dietary fibers and anti nutritional factors. All analyses were carried out in triplicate.

\section{Proximate composition}

The method of AOAC (1998) numbers was adopted for the estimation of crude proteins, crude fiber, ash and crude lipid. These analyses were necessary for the formulation of test diets.

Dietary fiber

The hemicellulose, cellulose and lignin contents were estimated using the method of Van Soest et al. (1999). Analyses of neutral detergent fiber (NDF) which comprised of hemicellulose, cellulose and lignin, acid detergent fiber (ADF) which comprised of cellulose and lignin and acid detergent lignin (ADL) which represented the lignin fraction were carried out. Hemicellulose and cellulose were obtained by "difference method", where hemicellulose was the difference between NDF and ADF while cellulose the difference between ADF and ADL.

\section{Hydrocyanide}

The method of Bradbury et al. (1991) was used. Hydrocyanide in plants occurred in combination with sugars as cyanogenic glycosides. Hydrocyanide was released when the glycosides were hydrolyzed by enzymes. The cyanogenic glycosides were hydrolyzed to volatile hydrocyanide, $\beta$-glucose and acetone. The released hydrocyanide reacted with alkakine picrate to form a red colored complex which was colorimetrically read at $510 \mathrm{~nm}$. The hydrocyanide concentration was obtained by multiplying the optical density by 396 and the results expressed as mg/100 $\mathrm{g}$ DM.

Phytate

The method of McCance and Widdowson (1947) was used. Phytate was extracted from the sample using $0.04 \mathrm{~N}$ hydrochloric acid. The phytate was precipitated as ferric chloride. The precipitate was converted to sodium phytate using sodium hydrohydrate before digestion with an acid mixture containing equal portions of concentrated sulphuric acid and 65\% hypochloric acid. The phytate was determined by estimation of the total amount phosphorus liberated after digestion. The liberated phosphorus was quantitated colorimetrically at $620 \mathrm{~nm}$ after color development with molybdate solution.

\section{Total oxalate}

The method of Dye (1956) was used. The total oxalate was extracted from the sample and precipitated as calcium salt. This was dissolved in hot $25 \%$ sulphuric acid and the concentration of oxalate in solution determined by titrating against potassium permanganate solution. The concentration of the total oxalate in the sample was calculated and expressed as $\mathrm{mg} / 100 \mathrm{~g} \mathrm{DM}$. 


\section{Formulation of experimental diets}

A total of 4 diets were prepared as per ICN (1992) protocol. Table 1 gives the composition of the experimental diets. The 3 test diets were formulated on the basis of their proximate compositions with all the diets containing $10 \%$ protein. The protein free diet served as control, while the spathe-based, spadix-based, and spadix + spathe-based in the ratio of approximately 0.9:1 served as the three test diets.

\section{Experimental design}

A rat feeding study was carried out to determine the protein quality and digestibility of the test diets based on rat growth. The protein free-diet provided an estimate of metabolic fecal protein (MFP) needed for the calculation of true protein digestibility (TPD).

Twenty four (24) weanling male wistar rats (Ratus novergicers) aged 21-23 days with an average weight of $31.25 \pm 3.09$ were used. The animals (rats) were divided into 4 groups $(n=6)$, with differences in average group weight not more than 3 as recommended by AOAC (1997). Control group was placed on protein free diet and the 3 test groups received respectively spathe-based, spadix-based and spadix + spathe-based diets.

The animal cages used were designed as described by Sarwar and Estatira (2003). The animal were housed individually in stainless steel screening bottom cages (permitting free dropping of fece) in temperature-controlled $\left(24-25 \quad{ }^{\circ} \mathrm{C}\right)$ and humidity-controlled (49-50\%) facility with
12 h light/dark cycle. Highly absorbent paper was placed under the cages to catch spilled food and to minimize contamination of feces with urine. The rats were given the corresponding diets and water ad libitum for 14 days and records of daily food consumption and body weights were kept from the fifth day. The first 4 days were considered acclimatization period.

\section{Protein digestibility determination}

The total collection of feces from individual rats was carried out during the last 5 days of the experiment. Records of daily food consumption and body weights were also kept during this collection period. At the end of this period, the bulk feces for each rat was lyophilized, weighed and ground. Total Nitrogen content of the ground feces was determined using the method of AOAC (1998). Six individual protein digestibility values per diet were then calculated using protein intake and fecal output data for each rat. True protein digestibility (TPD) values were calculated using the Sarwar and Peace (1986) equation.

$$
T P D=\frac{P I-(F P-M F P)}{P I} X 100,
$$

where $\mathrm{PI}=$ protein intake, $\mathrm{FP}=$ fecal protein and MFP $=$ metabolic fecal protein.

The amount of protein in the feces of rats fed the protein free diet was used as the estimate for MFP. Protein efficiency ratio (PER) and Net protein ratio (NPR) values (10 days), were calculated using the following equations (Sarwar and Peace, 1994).

Table 1: Composition of the experimental diets used in biological assay (g/100 g complete diet).

\begin{tabular}{lcccc}
\hline Ingredients & $\begin{array}{c}\text { Protein free diet } \\
\text { (control) }\end{array}$ & $\begin{array}{c}\text { Spathe } \\
\text { diet }\end{array}$ & $\begin{array}{c}\text { Spadix } \\
\text { diet }\end{array}$ & $\begin{array}{c}\text { Spadix + } \\
\text { spathe diet }\end{array}$ \\
\hline Corn starch & 15 & 15 & 15 & 15 \\
Corn oil & 5 & 5 & 5 & 5 \\
Mineral Mix (AIN-93G-MX) & 4 & 4 & 4 & 4 \\
Vitamins Mix (AIN-93G-VX) $^{\mathrm{b}}$ & 1 & 1 & 1 & 1 \\
Cellulose & 7.9 & 7.9 & 7.9 & 7.9 \\
Spathe $^{\mathrm{a}}$ & & 58.3 & & 29.2 \\
Spadix $^{\mathrm{a}}$ & & & 53.4 & 26.7 \\
Sucrose $_{\text {a: cooked and dehydrated samples, b:Supplied by Clab Lab. Bafoussam-Cameroon. }}$ &
\end{tabular}




$$
\begin{aligned}
& \mathrm{PER}=\frac{\text { sweight gain of test rat }}{\text { protein consumed by teat rat }} \\
& \mathrm{NPR}=\frac{\text { weightgain sf teat rat+waight los of non protein rat }}{\text { protein consumed by tast rat }}
\end{aligned}
$$

\section{Data analysis}

Statistical analyses were performed with the aid of SPSS for windows software programme (Release 11.0). Data were submitted to analysis of variance (ANOVA), and the test of Duncan was used to compare treatment means at a 5\% significance level.

\section{RESULTS}

Table 2a presents the proximate composition of the cooked and dehydrated spathe and spadix and table $2 b$ the antinutritional factors.

The spadix showed significantly $(\mathrm{p}<$ $0.05)$ higher values crude protein $(18.73 \%$ DM), crude lipid (10.8\% DM) and crude fiber (34.47\% DM) than spathe (17.14\% DM crude protein, $6.76 \%$ DM crude lipid and $22.71 \%$ DM crude fiber). However, spathe contained higher values of ash $(9.26 \% \mathrm{DM})$, cellulose (8.20\% DM), phytate $(0.06 \mathrm{mg} / 100 \mathrm{~g} \mathrm{DM})$, hydrocyanide $(0.25 \mathrm{mg} / 100 \mathrm{~g} \mathrm{DM})$ and total oxalate $(880.0 \mathrm{mg} / 100 \mathrm{~g} \mathrm{DM})$ than spadix (6.30\% DM ash, $4.32 \% \mathrm{DM}$ cellulose, 0.05 $\mathrm{mg} / 100 \mathrm{~g}$ DM phytate, $0.24 \mathrm{mg} / 100 \mathrm{~g} \mathrm{DM}$ hydrocyanide and $873.0 \mathrm{mg} / 100 \mathrm{~g} \mathrm{DM}$ total oxalate).

The true protein digestibility (TPD), protein efficiency ratio (PER) and net protein ratio (NPR) of standard and test diets are showed in table 3.

Spathe had significantly $(\mathrm{p}<0.05)$ the lowest TPD (53.0\%) compared to spadix and spadix + spathe which had approximately the same TPD, $60.6 \%$ and $60.7 \%$ respectively.

Spathe + spadix showed significantly $(\mathrm{p}<0.05)$ the highest PER value $(1.76)$ compared to spadix (1.38) and spathe (1.00). The results showed that spadix + spathe had significantly $(\mathrm{p}<0.05)$ the highest NPR (2.11), spadix (1.74) and spathe had the lowest (1.42).

The rat growth and food intake data needed to determine PER and NPR of the diets are also showed in table 3 . The rats fed spadix + spathe $(50.42 \mathrm{~g})$ registered the highest food consumption, spadix diet (49.16 g) and spathe diet (41.12 g) had the lowest.

The weight gain followed approximately the same trend as the food consumption. The spadix + spathe diet showed the highest weight gain $(8.86 \mathrm{~g} / 10$ days), spadix diet (6.76 g/10 days) and spathe diet (4.04 g/10 days) the lowest.

\section{DISCUSSION}

Chemical analyses are carried out to have an idea of the nutrient and non-nutrient contents of a food. The results of this study revealed different values of nutrients and nonnutrient in the spathe and spadix. This agrees with the studies of other researchers which revealed that different plant parts had different nutrient contents and nutrient availabilities (Hume and Purser, 1975; Ru and Fortune, 2000; Sundriyal and Sundriyal, 2004; Ebianadon et al., 2009 ). The nutrient values followed a trend similar to the findings of Agbor et al. (2005) though higher. However Agbor et al. (2005) used raw samples while this study involved cooked samples.

Also the NPR values of all the protein sources (spathe, spadix, and spadix plus spathe) were higher than the PER values (Table 3). The reason being that NPR method unlike the PER method credits protein used for both growth and maintenance (Sarwar, 1997). The protein required to prevent weight loss of rats fed the protein-free diet is assumed to be equivalent to the protein needed for maintenance. PER measures only growth and not maintenance, hence NPR and TPD are more reliable than PER to determine the protein quality of a food (Sarwar et al., 1989; Reis and Oliveira, 2008).

Digestibility indicates protein availability showing the amount of ingested protein that is hydrolyzed by digestive enzymes and absorbed by the body (Reis and Oliveira, 2008). Studies have revealed that the presence of certain anti-nutritional factors (phytate, cyanide, tannins, trypsin-inhibitors, hemagglutinins and gossypol) in plants can reduce protein digestibility (Frake and sharma, 1986; Aletor and Fetuga, 1988; Aletor, 1993; Aletor and Fasuyi, 1997). The results of this study showed different values of phytate, hydrocyanide and total oxalate in spathe 
Table 2a: Proximate composition of cooked spathe and spadix*.

\begin{tabular}{|c|c|c|c|c|c|c|c|c|c|}
\hline Sample & $\begin{array}{c}\text { Crude } \\
\text { lipid } \\
(\% \text { DM }) \\
\end{array}$ & $\begin{array}{c}\text { Crude } \\
\text { protein } \\
(\% \text { DM }) \\
\end{array}$ & $\begin{array}{c}\text { Ash } \\
(\% \text { DM) }\end{array}$ & $\begin{array}{c}\text { Crude } \\
\text { fibre } \\
(\% \text { DM }) \\
\end{array}$ & $\begin{array}{c}\text { NDF } \\
(\% \text { DM })\end{array}$ & $\begin{array}{c}\text { ADF } \\
(\% \text { DM })\end{array}$ & $\begin{array}{c}\text { ADL } \\
(\% \text { DM) }\end{array}$ & $\begin{array}{l}\text { Hemi- } \\
\text { cellulose } \\
(\% \text { DM })\end{array}$ & $\begin{array}{l}\text { Cellulose } \\
\text { (\% DM) }\end{array}$ \\
\hline Spathe & $6.76 \pm 0.06^{\mathrm{a}}$ & $17.14 \pm 0.03^{\mathrm{a}}$ & $9.26 \pm 0.10^{\mathrm{a}}$ & $22.71 \pm 0.12^{\mathrm{a}}$ & $34.35 \pm 0.12^{\mathrm{a}}$ & $15.34 \pm 0.22^{a}$ & $7.14 \pm 0.22^{\mathrm{a}}$ & $19.01 \pm 0.50^{\mathrm{a}}$ & $8.20 \pm 0.10^{\mathrm{a}}$ \\
\hline spadice & $10.8 \pm 0.03^{b}$ & $18.73 \pm 0.01^{\mathrm{b}}$ & $6.30 \pm 0.20^{\mathrm{b}}$ & $34.47 \pm 0.30^{\mathrm{b}}$ & $59.07 \pm 0.01^{\mathrm{b}}$ & $15.20 \pm 0.10^{\mathrm{a}}$ & $10.88 \pm 0.10^{\mathrm{b}}$ & $43.87 \pm 0.40^{\mathrm{b}}$ & $4.32 \pm 0.10^{\mathrm{b}}$ \\
\hline
\end{tabular}

*Value are means $(\mathrm{n}=3)$. Within a column, values with different superscripts are significantly, different $(\mathrm{p}<0.05)$. DM: Dry Matter, ADF: Acid detergent fiber, ADL: Acid detergent lignin.

Table 2b: Antinutritional factors in cooked spathe and spadix *.

\begin{tabular}{lccc}
\hline Sample & $\begin{array}{c}\text { hydrocyanide } \\
(\mathbf{m g} / \mathbf{1 0 0} \mathbf{~ g ~ D M})\end{array}$ & $\begin{array}{c}\text { Phytate } \\
(\mathbf{m g} / \mathbf{1 0 0} \mathbf{g ~ D M})\end{array}$ & $\begin{array}{c}\text { Total oxalate } \\
(\mathbf{m g} / \mathbf{1 0 0} \mathbf{~ g ~ D M})\end{array}$ \\
\hline Spathe & $0.25 \pm 0.03^{\mathrm{a}}$ & $0.06 \pm 0.02^{\mathrm{a}}$ & $880.0 \pm 2.25^{\mathrm{a}}$ \\
Spadix & $0.24 \pm 0.02^{\mathrm{a}}$ & $0.05 \pm 0.0^{\mathrm{a}}$ & $873.0 \pm 2.00^{\mathrm{b}}$ \\
\hline *Value are means $(\mathrm{n}=3)$. Within a column, values with different superscripts are significantly different $(\mathrm{p}<0.05)$. DM: Dry Matter.
\end{tabular}

Table 3: Growth of rats and protein efficiency ratios Net protein ratio and true protein digestibility values of experimental diets*.

\begin{tabular}{|c|c|c|c|c|c|}
\hline Diet & $\begin{array}{l}\text { Weight gain } \\
\text { (g/10 days) }\end{array}$ & $\begin{array}{l}\text { Food consumed } \\
\text { (g/10 days })\end{array}$ & PER & NPR & TPD \\
\hline Spathe & $4.04 \pm 1.60^{\mathrm{c}}$ & $41.12 \pm 3.19^{\mathrm{b}}$ & $1.00 \pm 0.43^{\mathrm{b}}$ & $1.42 \pm 0.41^{\mathrm{c}}$ & $53.00 \pm 3.67^{\mathrm{b}}$ \\
\hline Spadix & $6.76 \pm 1.14^{\mathrm{b}}$ & $49.16 \pm 2.58^{\mathrm{a}}$ & $1.38 \pm 0.22^{\mathrm{a}}$ & $1.74 \pm 0.22^{\mathrm{b}}$ & $60.62 \pm 3.88^{\mathrm{a}}$ \\
\hline Spadix +spathe & $8.86 \pm 1.36^{\mathrm{a}}$ & $50.42 \pm 1.02^{\mathrm{a}}$ & $1.76 \pm 0.28^{\mathrm{a}}$ & $2.11 \pm 0.28^{\mathrm{a}}$ & $60.72 \pm 5.32^{\mathrm{a}}$ \\
\hline
\end{tabular}

NPR: Net protein ratio, TPD: True Protein Digestibility. 
and spadix, with spathe having higher values. The presence of these anti-nutritional factors in spathe could have contributed to the lower TPD recorded for spathe. Recent knowledge revealed that the presence of phytate in foods reduced protein digestibility (Sarwar et al., 2005; Osman, 2007). Also, dietary fiber could have an adverse effect on protein digestibility (Mongeau et al., 1989; Eggum, 1995; Hughes et al., 1996; Deges et al., 2007). However, studies involving different types of dietary fiber showed that hemicellulose had no effect on protein digestibility while cellulose, pectin and gum decreased protein digestibility (Fleming and Lee, 1983; Mongeau et al., 1989; Urbano and Goni, 2002; Owusu-Asiedu et al., 2006). Young and Pellet (1994) explained that the plant protein can be encased in cellulose walls, which are hard to penetrate and this makes proteins less accessible to digestive enzymes. This study recorded higher levels of cellulose in spathe than in spadix. This could have also contributed to the lower TPD observed in spathe.

This study has demonstrated that rats fed on spadix diet had significantly $(p<0.05)$ higher NPR and TPD values than those fed spathe diet. This suggests that the proteins were more available in spadix than in spathe. The presence of certain inherent factors (phytate, cyanide and cellulose) may have militated against protein availability. However, NPR and TPD values were improved with the spadix + spathe diet. Hence, the consumers of Colocasia esculenta var. antiquorum flower are advised to consume either the spadix alone or a mixture of spadix + spathe and not spathe alone.

\section{ACKNOWLEDGEMENTS}

We are grateful to Dr. Fritz Oben and members of the Animal Nutrition Laboratory for the assistance.

\section{REFERENCES}

Agbor EE, Umoh IB, Itam EH, Enyong EU. 2005. Proximate and mineral composition of flower (spathe and spadix) of Colocaasia esculenta var. antiquorum grown in Dschang, Cameroon. J. Pure and Applied Sci., 11(4): 491-493.

Agbor-Egbe T. 1991. Biochemical changes occurring during storage of Colocasia ssp. and Xanthsoma spp. cormels under tropical ambient conditions. In IFS Proceedings of Regional Worshop on Traditional Foods Quality and Nutrition, Westly A, Reilby PJA (eds). Echaris Press: Manila; 171-178.

Aletor MVA, Adeogun DA. 1995. Nutrient and anti-nutrient components of some tropical leafy vegetables. $F d$. Chem., 53: 375-379.

Aletor VA. 1993. Cyanide in garri. An assessment of some aspects of the nutrition, biochemistry and hematology of rats fed garri containing varying residual cyanide levels. Int. J. Food Sci. Nutr., 44: 289-295.

Aletor VA, Fasuyi AO. 1997. Nutrient composition and processing effect on cassava leaf (Manihot esculenta Cranzt) anti-nutrients. Proc. of the $2^{\text {nd }}$ Ann. Conf of Anim. Sci. Ass. of Nigeria (Asan), pp 231-242.

Aletor VA. Fetuga BL. 1988. Dietary interaction of Lima bean (Phaseolus lunatus) trypsin inhibitor, haemagglutinin and cyanide: 1. Effect on growth performance, nitrogen utilization and physio pathology in growing rats. J. Anim Physiol. Anim. Nutr., 60: 113-122.

AOAC (Association of Official Analytical Chemists). 1997. Official Methods of Analysis of AOAC International (16 ${ }^{\text {th }}$ edn). AOAC: Washington.

AOAC (Association of Official Analytical chemists). 1998. Official methods of analysis of AOAC International $\left(18^{\text {th }}\right.$ edn). AOAC: Washington.

Bradbury MG, Egan SU, Bradbury JH. 1999. Determination of all forms of cyanogens in cassava roots and cassava products using picrate paper kits. J. Sci. Fd. Agr., 79: 593-601.

Déges L, Halas V, Babinsky L. 2007. Effect of dietary fiber on protein and fat digestibility and its consequences on diet formulation for growing and fattening pigs: A review. Acta Agriculturae Scandinavica Section A-Ani Sciences, 37(1): 1-9.

Dye WB. 1956. Studies on Halogenten glomeratus. Weed, 4: 55-60.

Ebiamadon AB, Umoren EU, Fraideh B, Pedro MM, Jorge FSF, Devanand L, 
Xianli W, Ronald LP. 2009. Nutritional characterization and antioxidant capacity of different tissues of Artemisia annua L. Fd. Chem., 115(4): 1240-1246.

Ejoh AR, Mbiapo FT, Fokon E. 1996. Nutrient composition of the leaves and flowers of Colocasia esculenta and fruits of Solanum Melongena. Plant Food hum. Nutr., 49(2): 107-112.

Eggum BO. 1995. The influence of dietary fiber on protein digestibility and utilization in monogastrics. Achives of Animal Nutrition, 48(1-2): 89-95.

Fleming SE, Lee B. 1983. Growth performances and intestinal transit time of rats feed purified and natural dietary fibers. J. Nutr., 113(3): 592-601.

Frake RA, Sharma EP. 1986. Comparative metabolism of linamarin and amaygdalin in harvester. Food Chem. Toxicol., 24: 417-420.

Hughes JS, Acevedo E, Bressani R, Swanson BG. 1996. Effects of dietary fiber and tannis on protein utilization in dry beans (Phaseolus vulgaris). Food Research International, 29(3-4): 331-338.

Hume ID, Purser BD. 1975. Ruminal and post-ruminal protein digestion in sheep fed on Subterran an clover harvested at four stages of maturity. Aus. J. Agr. Res., 26: 199-208.

ICN-International Conference of Nutrition. 1992. Biochemical catalog. Rome. Cleavland.

Kannan S, Nielsen SS, Mason AC. 2001. Protein digestibility-corrected Amino acid scores for bean and bean-price infant weanling food products. J. Agric. Fd. Chem., 49(10): 5070-5074.

Mc Cance RA, Widdowson EM. 1947. Antivitamins in food: Phytic Acid. $J$. Hyg, Camb., 45: 59-64.

Mongeau R, Sarwar G, Peace RW, Brassard R. 1989. Relationship between dietary fiber levels and protein digestibility in selected foods as determined in rats. Revue Plant Foods for Human Nutrition, 39(1): 45-51.

Oguntona T. 1998. Green leafy vegetables. In Nutritional Quality of Plant Foods, Osagie Al. Eka UO (eds). Post Harvest Research Unit, University of Benin: Benin City; 120-133.
Osman MA. 2007. Changes in nutrient composition, trypsin inhibitor, phytate, tannins and protein digestibility of Dolichos Lablab seeds (Lablab putrpuresus (L) sweet) occurring during germination. J. Fd. Tech., 5(4): 294-299.

Owueme IC. 1999. Taro Cultivation in Asia and the Pacific. RAP Publication: Bangkok.

Owusu-Asiedu A, Patience JF, Laarveld B, Van kessel AG, Simmins PH, Zijlstra RT. 2006. Effects of guar gum and cellulose on digesta passage rate, ileal microbial populations, energy and protein digestibility, and performance of grower pigs. J. Anim. Sci., 84: 843-852.

Reis LS, Oliveira TC. 2008. Ostrich (Strutio camelus) meat protein quality and digestibility. Revista Brasileira de Ciencia Avicola, 10(3): 195-200.

$\mathrm{Ru}$ Y, Fortune JA. 2000. Variation in nutritional value of parts in subterranean Clover (Triflolium Subterranean L). Aus. J. Exp. Agri., 40: 397-403.

Sarwar G. 1997. The protein digestibilitycorrected amino acid score method over estimates quality proteins containing antinutritional factors and of poorly digestible protein supplemented with limiting amino acids. J. Nutr., 127: 758764.

Sarwar G, Cockell KA, Estatira S. 2005. Effects of antinutritional factors on protein digestibility and amino acid availability in foods. J. AOAC International, 88(3): 967-987.

Sarwar G, Estatira S. 2003. Protein digestibility and quality in products containing antinutritional factors are adversely affected by old age in rats. $J$. Nutr., 133: 220-225.

Sarwar G, Peace RW. 1986. Comparisons between true digestibility of total nitrogen and limiting amino acids in vegetable proteins J. Nutr., 116: 1172-1184.

Sarwar G, Peace RW. 1994. The protein quality of some enteral products is inferior to that of casein as assessed rat growth methods digestibility-corrected amino acid scores. J. Nutr., 124: 22232232.

Sarwar G, Peace RW, Botting HG, Brule D. 1989. Digestibility of protein and amino 
acids in selected foods as determined by a rat balance method. Plant Food Hum. Nutr., 1(1): 23-32.

Sundriyal M, Sundriyal RC. 2004. Wild edible plants of the Sikkin Himalaya: Nutritive values of selected species. Economic Botany, 58(2): 286-299.

Urbano MG, Goni I. 2002. Bioavailability of nutrients in rats fed on edible Seaweeds, Nori (Parphyra tenera) and Wakame (Undaria pinnalifida), as a source of dietary fibre. Fd. Chem., 76(3): 281-286.
Van Soest PJ, Robertson JD, lewis BA. 1991. Methods for analyzing dietary fibre, neutral detergent fibre and non-starch polysaccharides in relation to animal nutrition. J. Dairy Sci., 74: 3583-3697.

Wilfried L. 1999. Taro (Colocasia esculenta). Ethnobotanical leaflets. Southern Illinois University, Carbondale.

Young VR, Pellette PL. 1994. Plant proteins in relation to human protein and amino acid requirements. Am. J. Clin Nutr., 59(1): 1203-1212. 